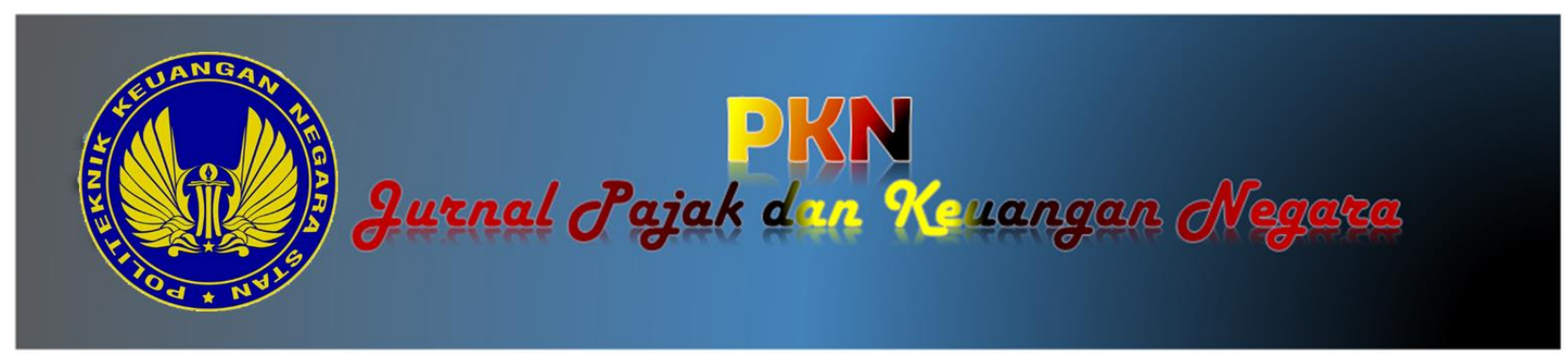

\title{
ANALISIS ASPEK PERPAJAKAN PADA FINTECH KHUSUSNYA PEER TO PEER (P2P) LENDING UNTUK MENYUSUN ATURAN PERPAJAKAN
}

\author{
Vissia Dewi Haptari \\ PKN STAN-PDIE Universitas Trisakti \\ Irwan Aribowo \\ PKN STAN-FIA Universitas Brawijaya
}

Alamat Korespondensi: vissiadewih@pknstan.ac.id atau irwan_aribowo@pknstan.ac.id

INFORMASI ARTIKEL
Diterima Pertama
[27 September 2019]
Dinyatakan Diterima
[23 Oktober 2019]
KATA KUNCI:
Fintech , Peer To Peer Lending, Peraturan
Perpajakan

KLASIFIKASI JEL:

$\mathrm{H} 2, \mathrm{H} 3, \mathrm{M} 1$

\section{ABSTRACT}

Financial technology ('Fintech ') shifts the paradigm of financial transactions and demands more rapid and adaptive change. Based on the results of BBVA's 2017 study, domestic business financing needs will be around IDR 1,600 trillion. In fact, only IDR 600 trillion can be disbursed annually through banks, capital markets and finance companies. Only 11 million of the 60 million SMEs can obtain loans from banks. Sixty percent of that number is based on the island of Java. Indonesia is expected to spend a small and medium business fund of US\$ 54 billion by 2020, with more than 57 million micro-businesses proposed bankable

The purpose of this study is to discuss taxation rules as a regulator function and budget function in the fintech industry specifically the Peer to Peer loan business model (P2P lending) as part of the fintech business model. Special licenses related to the transaction and taxation model are also needed to make it easier and can be arranged according to the tax compliance.

The government as regulator must issue regulations regarding the development of the P2P lending industry which includes aspects of taxation, namely subjects, objects, tax rates and collection mechanisms. Development of a special P2P lending model need to be anticipated quickly because they have to income the state.

\section{ABSTRAK}

Teknologi keuangan ('Fintech ') menggeser paradigma transaksi keuangan dan menuntut perubahan regulasi yang lebih cepat dan adaptif. Didasarkan pada hasil penelitian BBVA tahun 2017, kebutuhan pembiayaan usaha di dalam negeri akan menjadi sekitar Rp1.600 triliun. Kenyataannya, hanya Rp600 triliun yang bisa dicairkan setiap tahun melalui perbankan, pasar modal, dan multifinance. Kesenjangan ini lebih lanjut ditunjukkan pada kenyataan bahwa hanya 11 juta dari 60 juta UKM dapat memperoleh pinjaman dari bank. Enam puluh persen dari angka itu berbasis di pulau Jawa. Indonesia diperkirakan akan mengalami kesenjangan pembiayaan usaha kecil dan menengah sebesar US\$ 54 miliar pada tahun 2020, dengan lebih dari 57 juta bisnis mikro yang berpotensi bankable.

Tujuan dari penelitian ini adalah untuk mengidentifikasi aturan perpajakan sebagai fungsi regulator dan fungsi anggaran dalam industri fintech khususnya bisnis model pinjaman Peer to Peer ( P2P lending) sebagai bagian dari bisnis model fintech. Diperlukan juga pengaturan khusus dalam ketentuan pajak yang terkait dengan model transaksi dan pengenaan pajak agar lebih sederhana dan dapat memastikan kepatuhan wajib pajak.

Pemerintah sebagai regulator perlu mengatur secara khusus peraturan perpajakan sebagai dampak perkembangan industri $P 2 P$ lending yang mencakup aspek perpajakan yaitu subjek, objek, tarif pajak dan mekanisme pemungutan. Pengembangan fintech khususnya bisnis model $P 2 P$ lending perlu diantisipasi dengan cepat karena mempengaruhi penerimaan negara 


\section{PENDAHULUAN}

\subsection{Latar Belakang}

Krisis keuangan pada tahun 2008 telah mengarah pada pengembangan sistem keuangan yang lebih modern. Salah satu inisiatif adalah untuk mengadopsi teknologi informasi dan internet untuk meningkatkan layanan keuangan ( $\mathrm{Ng}$, et al, 2017). Teknologi informasi memainkan peran utama dalam transformasi perbankan. Saat ini, pasar keuangan sangat mempengaruhi bisnis perbankan. Salah satu contohnya adalah fintech, pemain baru yang ikut memasuki industri jasa keuangan dengan basis teknologinya (Arnoud W.A.Boot, 2017). Fintech mempengaruhi lembaga keuangan, regulator, pelanggan, dan pedagang di berbagai industri. Teknologi digital ini mendorong munculnya sistem pembayaran nontradisional, pertukaran uang, peer-to-peer $(P 2 P)$ dan peningkatan turbulensi di pasar mata uang (Carmen Leong, 2017).

Perkembangan teknologi keuangan (fintech) menunjukkan perkembangan pesat, karena inovasi dalam pelayanan keuangan yang memberikan kemudahan di antara para pelaku keuangan, terutama untuk pinjaman peer to peer. Sebagai contoh adalah pasar pinjaman peer-to-peer di China yang telah menjadi pasar pinjaman paling besar di dunia. Pertumbuhan pinjaman peer-to-peer online yang pesat di China didorong oleh adanya pasokan pendanaan dari investor ritel. Selain itu, didorong pula oleh permintaan untuk akses keuangan dari individu dan dari pemilik usaha kecil dan mikro. Dengan menerapkan inovasi dalam keuangan alternatif, pinjaman antar rekan di China menciptakan saluran informasi kredit baru dan meningkatkan akses ke pembiayaan (Asosiasi Akuntan Bersertifikat Chartered, 2015). China Economic Journal 2016 dalam artikel yang ditulis oleh Shen Yan, dan Yi Ping Hua menjelaskan tentang Internet Financial yang telah diterapkan di China selama lebih dari 10 tahun. Sejak Januari 2014, aktivitas Internet Finansial telah tumbuh sekitar 100 persen per tahun. Sebagai contoh, platform $P 2 P$ telah meningkat secara signifikan.

Di Indonesia pengembangan fintech didasarkan pada hasil penelitian BBVA "Fintech di Emerging ASEAN Trends and Prospects in 2017" sebagai berikut:

Otoritas Jasa Keuangan Indonesia (OJK) memperkirakan bahwa sebenarnya kebutuhan pembiayaan usaha di dalam negeri akan menjadi sekitar Rp1.600 triliun. Kenyataannya, hanya Rp600 triliun yang dapat dicairkan setiap tahun melalui perbankan, pasar modal, dan multifinance.

Kesenjangan ini lebih lanjut ditunjukkan pada kenyataan bahwa hanya 11 juta dari 60 juta UKM dapat memperoleh pinjaman dari bank. Enam puluh persen dari angka tersebut berada di pulau Jawa. Indonesia diperkirakan akan mengalami kesenjangan pembiayaan usaha kecil dan menengah sebesar US\$ 54 miliar pada tahun 2020, dengan lebih dari 57 juta bisnis mikro yang berpotensi bankable. Data yang sebagaimana terdapat pada tabel 1.1. menunjukkan perkembangan fintech di Indonesia.
Table 1.1 Model Fintech di Indonesia tahun 2017

\begin{tabular}{|c|l|l|}
\hline No & \multicolumn{1}{|c|}{ Model Fintech } & \multicolumn{1}{c|}{ Jumlah } \\
\hline 1. & Pinjaman & US\$29.4 juta \\
\hline 2. & Pembayaran & US\$23 juta \\
\hline 3. & Layanan Bisnis & US\$3.5 juta \\
\hline 4. & Mata Uang Digital & US\$50.000 \\
\hline 5. & Investasi & Tidak terungkap \\
\hline
\end{tabular}

Sumber: Website Tech in Asia

Nizal (2017) dalam studinya tentang fintech di Indonesia menjelaskan tentang konsep dasar, faktor pendorong inovasi, pengembangan fintech, implikasi dan risiko yang dibawanya. Penulis menemukan bahwa perkembangan spektakuler terjadi pada tahun 20142016, di mana jumlah perusahaan fintech meningkat sebanyak 125 perusahaan, sehingga total menjadi 165 perusahaan (meningkat sekitar $312,5 \%$ ). Pada tahun 2016, pembiayaan online memiliki pangsa pasar terbesar dari pinjaman bisnis peer-to-peer, pinjaman konsumen peer-to-peer, dan crowdfunding secara berurutan. Otoritas Jasa Keuangan (OJK) menyatakan bahwa dari banyak perusahaan fintech, terutama $P 2 P$ lending yang terdaftar dan berlisensi hingga 8 Juni 2018, adalah sebanyak 63 perusahaan. Tabel 1.2. menunjukkan perkembangan pendanaan fintech di Indonesia.

Table 1.2 Perkembangan Pendanaan Fintech di Indonesia

\begin{tabular}{|c|c|c|c|}
\hline $\begin{array}{l}\text { Indikator Lender } \\
\text { (orang) }\end{array}$ & Q4/2016 & $\begin{array}{l}\text { Agustus } \\
2017\end{array}$ & $\%$ \\
\hline - Jawa & 10.502 & 39.706 & 278 \\
\hline - Luar Jawa & 1.000 & 7.918 & 692 \\
\hline Total & 12.145 & 48.034 & 296 \\
\hline \multicolumn{4}{|l|}{$\begin{array}{l}\text { Borrower } \\
\text { (orang) }\end{array}$} \\
\hline - Jawa & 49.489 & 113.192 & 130 \\
\hline - Luar Jawa & 1.275 & 6.145 & 382 \\
\hline Total & 50.863 & 120.174 & 136 \\
\hline \multicolumn{4}{|l|}{$\begin{array}{l}\text { Akumulasi } \\
\text { Pendanaan (Rp } \\
\text { juta) }\end{array}$} \\
\hline - Jawa & 228.965 & 1.203 .175 & 426 \\
\hline - Luar jawa & 13.524 & 242.751 & 1695 \\
\hline Total & 242.489 & 1.446 .466 & 497 \\
\hline
\end{tabular}

Sumber: OJK

Perubahan peraturan dan perkembangan teknologi setelah Krisis Keuangan Global 2008 mengubah sifat pasar keuangan, layanan dan institusi. Pada titik fenomena ini terdapat teknologi pengaturan atau "RegTech" penggunaan teknologi, khususnya teknologi informasi, dalam konteks pemantauan regulasi, pelaporan, dan kepatuhan. Pengembangan RegTech mengarah pada perubahan paradigma yang membutuhkan rekonseptualisasi regulasi keuangan (Douglas W. Arner, dkk, 2017).

Dengan berkembangnya fintech di Indonesia muncullah Fintech Indonesia Association (AFI) pada September 2015 yang menjadi pusat perhatian para 
pengusaha, sebagaimana telah dilakukan pengaturan oleh Otoritas Jasa Keuangan dalam aturan Peraturan Otoritas Jasa Keuangan No. 77 / POJK.01 / 2016 Tentang Layanan Peminjaman Teknologi Informasi (POJK LPUMBTI). Dengan tujuan menyediakan mitra bisnis yang dapat diandalkan dan andal untuk membangun ekosistem fintech di Indonesia yang berasal dari perusahaan Indonesia dan untuk Indonesia sendiri, perusahaan telah mengumpulkan sekitar $30 \%$ dari semua pengguna fintech di Indonesia.

Perkembangan pengguna fintech juga tumbuh, dari awalnya 7\% pada 2006-2007 menjadi 78\% pada tahun 2017. Jumlah pengguna terdaftar per 2017 adalah 135-140 perusahaan. Deputi Gubernur Senior BI Mirza Adityaswara mengatakan berdasarkan data statistik, total nilai transaksi fintech di Indonesia tahun lalu diperkirakan mencapai US \$15,02 miliar (Rp202,77 triliun). Angka itu tumbuh $24,6 \%$ dari tahun sebelumnya. Pada 2017, total nilai transaksi di pasar fintech diproyeksikan mencapai US\$ 18,65 miliar (Rp251,775 triliun).

Perubahan teknologi dan inovasi keuangan yang telah dialami oleh perbankan komersial selama 25 tahun terakhir menjelaskan peran sistem keuangan dalam ekonomi dan bagaimana perubahan dalam teknologi dan inovasi keuangan dapat meningkatkan kesejahteraan sosial (W. Scott Frame dan Lawrence J., 2016 ) dan meningkatkan kegiatan ekonomi sehingga ada potensi dalam hal penerimaan pajak, sebagaimana informasi dari data penerimaan pada sektor keuangan pada semester I tahun 2018 adalah sebesar Rp88,17 T. Potensi dari penerimaan tersebut memiliki kontribusi dalam meningkatkan perekonomian dari sektor penerimaan negara.

\section{LANDASAN TEORI}

Model bisnis fintech adalah hasil inovasi pada layanan keuangan yang memiliki beberapa konsep terkait, seperti teori stakeholder, teori agensi, konsep manajemen publik baru, dan konsep tentang fintech dan perpajakan. Selain berdasarkan konsep-konsep maupun teori ilmiah dalam memahami karakteristik proses bisnis $P 2 P$ lending, dan karena telah banyak dilakukan penelitiantentang praktik-praktik fintech dan khususnya P2Plending, maka hasil penelitian tersebut dapat untuk mengidentifikasi aspek perpajakannya.

\subsection{Teori Umum}

Dalam aktivitas bisnis, entitas perusahaan memiliki hubungan dengan pihak internal dan eksternal, yang memiliki kepentingan dalam perusahaan. Beberapa penelitian menggambarkan kegiatan ini sebagai pemangku kepentingan di mana perusahaan tidak hanya melakukan kegiatan operasional tetapi juga mengakomodasi kepentingan banyak pihak, seperti pemegang saham, kreditur, konsumen, pemasok, pemerintah, masyarakat, analis dan lain-lain. Menurut Deegan (2004) teori stakeholder menyatakan bahwa semua pemangku kepentingan memiliki hak untuk memperoleh informasi tentang kegiatan perusahaan yang dapat mempengaruhi pengambilan keputusan mereka.

Dalam sistem ekonomi yang melibatkan suatu entitas di mana ada hubungan pengaruh timbal balik dan saling menghakimi menimbulkan otoritas dalam mencapai tujuan. Ini dapat ditunjukkan dalam teori agensi, di mana teori ini menjelaskan hubungan antara pemegang saham sebagai prinsipal dan manajemen sebagai agen. Manajemen bertanggung jawab kepada pemegang saham karena mereka dikontrak untuk kepentingan pemegang saham. Jensen dan Meckling (1976) mendeskripsikan hubungan agensi sebagai hubungan agensi sebagai "kontrak" yang mana seorang atau lebih (para pelaku) melibatkan orang lain (agen) untuk melakukan beberapa layanan atas nama mereka yang melibatkan mendelegasikan beberapa otoritas pengambilan keputusan kepada agen tersebut. Definisi lainnya adalah bahwa teori ini menjelaskan hubungan keagenan di mana kontrak dapat dilakukan oleh satu orang atau lebih untuk memesan orang lain (agen) untuk melakukan pekerjaan atas nama kepala, selain itu juga dapat membuat keputusan mewakili prinsipal sehingga jika kedua belah pihak sudah memiliki kesepakatan yang sama dalam pencapaian tujuan, sehingga agen akan bertindak sesuai dengan kepentingan prinsipal.

Pengaturan keuangan dan ekonomi tidak dapat dipisahkan dari peran pemerintah untuk membuat peraturan, sehubungan dengan peran pemerintah untuk melakukan pelayanan sektor publik. Hal ini sejalan dengan pengembangan manajemen oleh pemerintah dengan manajemen publik baru (New Publik Management/NPM), yang mana peran pemerintah menjadi lebih efektif dan efisien dalam rangka meningkatkan efisiensi, efektivitas kinerja pelayanan publik dalam birokrasi moderen. NPM ini telah mengalami berbagai perubahan orientasi menurut Ferlie, Ashbuerner, Filzgerald dan Pettgrew di Keban (2004: 25), yaitu: orientasi layanan publik menekankan kualitas, misi, dan nilai-nilai yang ingin dicapai oleh organisasi publik, memberikan perhatian lebih besar pada aspirasi, kebutuhan dan partisipasi dari pengguna dan warga negara. Dalam hal ini, termasuk pula pembelajaran sosial dalam pemberian layanan publik dan penekanan pada evaluasi kinerja berkelanjutan, partisipasi masyarakat dan akuntabilitas. Perkembangan fintech sangat dipengaruhi oleh pemangku kepentingan dan beberapa elemen yang lebih dikenal sebagai ekosistem, sebagaimana terlihat dalam gambar 2.1.: 
Gambar 2.1 Ekosistem pada fintech

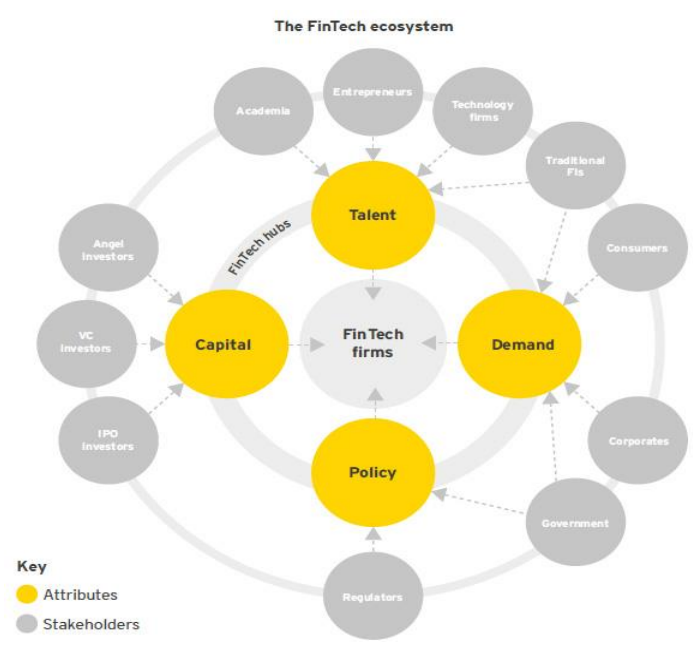

Source: Ernst \& Young, 2016.

Empat atribut inti dari ekosistem fintech yang berfungsi dengan baik: 1) Talent: ketersediaan layanan teknis, keuangan, dan kewirausahaan; 2) Modal: ketersediaan sumber daya keuangan untuk start-up; 3) Kebijakan: kebijakan pemerintah terhadap regulasi, pajak, dan pertumbuhan sektor; 4) Permintaan: permintaan klien akhir di seluruh konsumen, perusahaan dan lembaga keuangan.

\subsection{Regulasi Pemerintah}

Terkait dengan regulator dalam proses bisnis fintech lembaga pemerintah di Indonesia yang mendapat mandat sebagai lembaga regulator yang berperan adalah lembaga keuangan (Bank Sentral dan Otoritas Jasa Keuangan), komunikasi dan lembaga telekomunikasi, Peraturan Fintech di Indonesia diterbitkan sebagai berikut:

1) Peraturan Bank Indonesia Nomor 19/12 / PBI / 2017 tentang Penerapan Teknologi Keuangan

2) Peraturan Otoritas Jasa Keuangan Nomor 77/ POJK.01/2016 Tentang Layanan Peminjaman Teknologi Informasi (POJK LPUMBTI)

3) Peraturan Kominfo dalam Undang-Undang Nomor 11 Tahun 2008 tentang Informasi dan Transaksi Elektronik

Berikut ini adalah peraturan yang telah dibuat oleh Bank Indonesia, Otoritas Jasa Keuangan dan Kementerian Komunikasi dan informasi. Hingga saat ini ada 3 (tiga) regulasi yang terkait dengan industri fintech, yaitu:

1. Peraturan Bank Indonesia Nomor 19/12/PBI/2017 tentang Penerapan Teknologi Keuangan. Peraturan Bank Indonesia tersebut diterbitkan dengan latar belakang:

a. pengembangan teknologi dan sistem informasi terus menghasilkan inovasi, terutama yang terkait dengan teknologi keuangan untuk memenuhi berbagai kebutuhan masyarakat termasuk akses ke layanan keuangan dan pemrosesan transaksi;

b. perkembangan teknologi keuangan di satu sisi terbukti membawa manfaat bagi konsumen, pelaku bisnis dan ekonomi nasional, tetapi $\mathrm{d}$ sisi lain memiliki potensi risiko yang jika tidak dimitigasi dengan baik dapat mengganggu sistem keuangan;

c. ekosistem teknologi keuangan perlu terus dipantau dan dikembangkan untuk mendukung terciptanya stabilitas moneter, stabilitas sistem keuangan, dan sistem pembayaran yang efisien, lancar, aman dan andal untuk mendukung pertumbuhan ekonomi nasional yang berkelanjutan dan inklusif;

d. penerapan teknologi keuangan harus menerapkan prinsip-prinsip perlindungan konsumen serta manajemen risiko dan kehatihatian dengan memperhatikan perluasan akses, kepentingan nasional, serta standar dan praktik internasional yang berlaku;

e. tanggapan kebijakan Bank Indonesia terhadap pengembangan teknologi keuangan harus tetap sinkron, harmonis dan terintegrasi dengan kebijakan Bank Indonesia lainnya seperti pemrosesan transaksi pembayaran dan gateway pembayaran nasional dan perlu dikoordinasikan dengan otoritas yang relevan.

2. Peraturan Otoritas Jasa Keuangan No. 77/POJK.01/2016 Tentang Layanan Peminjaman Teknologi Informasi (POJK LPUMBTI). Berdasarkan peraturan tersebut, ada tiga pihak yang terikat langsung atau tidak langsung, yaitu Pemberi Pinjaman, Debitur/borrower, dan Penyedia Layanan Peminjaman Teknologi informasi. Secara rinci, definisi para pihak adalah sebagai berikut:

a. Penyedia Layanan Peminjaman Teknologi Informasi, yang selanjutnya disebut Penyelenggara, adalah badan hukum Indonesia yang menyediakan, mengelola, dan mengoperasikan layanan peminjaman dan teknologi Informasi.

b. Debitur/borrower adalah orang dan/atau badan hukum yang memiliki hutang karena perjanjian layanan pinjaman

c. Pemberi pinjaman adalah orang, badan hukum, dan/atau badan usaha yang memiliki piutang karena perjanjian Layanan Berdasarkan ketentuan POJK dapat disimpulkan bahwa P2P Lending adalah layanan yang disediakan oleh perusahaan kepada masyarakat dengan tujuan meminjam uang secara online melalui situs web atau aplikasi yang dikelola oleh perusahaan.

3. Undang-undang Nomor 11 Tahun 2008 tentang Informasi dan Transaksi Elektronik sebagaimana telah diubah dengan Undang-undang Nomor 19 Tahun 2016 (UU ITE) dan Peraturan Menteri Komunikasi dan Informatika Nomor 20 tahun 2016 tentang Perlindungan Data Pribadi dalam Sistem Elektronik (PM) 20/2016) mencantumkan sanksi bagi mereka yang melanggar.

\subsection{Konsep, teori dan regulasi tentang perpajakan}

Terkait dengan peraturan pajak perlu dipahami beberapa hal terkait konsep, teori dan regulasi perpajakan. Pertama, harus dipahami tentang fungsi perpajakan pada ekonomi, bahwa perpajakan 
memiliki beberapa fungsi dalam perekonomian, yaitu fungsi pertama adalah fungsi anggaran (budgeter) karena pajak adalah sumber pendapatan keuangan negara melalui pengumpulan dana atau uang dari pembayar pajak ke kas negara untuk membiayai pembangunan nasional atau pengeluaran negara lainnya. Fungsi pajak ini bertujuan untuk menyeimbangkan belanja negara dengan penerimaan negara. Fungsi pajak kedua adalah mengatur (regulasi). Pajak merupakan alat untuk menerapkan atau mengatur kebijakan negara di bidang sosial dan ekonomi, seperti digunakan untuk menghambat inflasi; digunakan juga untuk mendorong kegiatan ekspor. Pajak dapat memberikan perlindungan atau perlindungan untuk barang yang diproduksi di dalam negeri, misalnya: Pajak Pertambahan Nilai (PPN); Pajak dapat mengatur dan menarik investasi modal yang membantu ekonomi menjadi lebih produktif. Fungsi ketiga adalah fungsi distribusi yaitu pajak dapat digunakan untuk menyesuaikan dan menyeimbangkan distribusi pendapatan dengan kebahagiaan dan kesejahteraan masyarakat. Dalam fungsi ini, diharapkan pajak akan dapat digunakan untuk hal-hal yang mampu menyeimbangkan kesejahteraan masyarakat seperti bantuan operasional sekolah, bantuan tunai langsung, bantuan beras untuk orang miskin, dan sebagainya. Fungsi pajak keempat adalah fungsi stabilisasi. Dalam fungsi ini, pajak dapat digunakan untuk menstabilkan kondisi ekonomi, misalnya untuk mengatasi inflasi. Pemerintah menetapkan pajak yang tinggi, sehingga jumlah uang yang beredar dapat dikurangi. Sementara itu, untuk mengatasi kelesuan ekonomi atau deflasi, pemerintah menurunkan pajak, sehingga jumlah uang yang beredar dapat ditingkatkan dan deflasi dapat diatasi.

Dalam peraturan perpajakan diatur pula mengenai subjek, objek, dan tarif pajak. Subjek adalah adalah orang, entitas, atau entitas lain yang telah memenuhi kondisi subyektif, yaitu berdomisili atau berdomisili di Indonesia. Subjek pajak akan menjadi wajib pajak jika memenuhi persyaratan obyektif, sedangkan dalam peraturan perpajakan, objek pajak adalah sesuatu yang dapat dikenakan pajak. Objek pajak penghasilan adalah penghasilan. Pengertian penghasilan menurut undang-undang pajak penghasilan adalah setiap tambahan kemampuan ekonomi yang diterima atau diperoleh oleh pembayar pajak, baik dari Indonesia maupun dari luar Indonesia, yang dapat digunakan untuk konsumsi atau untuk meningkatkan kekayaan wajib pajak yang bersangkutan, dengan nama dan dalam bentuk apapun. Tarif pajak adalah jumlah dari nilai hutang yang harus dibayarkan pembayar pajak kepada pemerintah sesuai dengan hukum yang berlaku.

Dalam menyusun suatu kebijakan perpajakan harus mempertimbangkan 4 variabel, yaitu: 1) Jenis pajak yang dipungut, 2) Subjek yang dikenakan pajak, 3) Objek pajak yang akan dipungut, dan 4) Sistem atau prosedur pemungutan pajak,

Sistem pemungutan atau prosedur pajak, yakni:

a. Self Assessment System
Ciri-ciri sistem pemungutan pajak Self Assessment:

1) Penentuan besaran pajak terutang dilakukan oleh wajib pajak itu sendiri.

2) Wajib pajak berperan aktif dalam menuntaskan kewajiban pajaknya mulai dari menghitung, membayar, hingga melaporkan pajak.

3) Pemerintah tidak perlu mengeluarkan surat ketetapan pajak, kecuali jika wajib pajak telat lapor, telat bayar pajak terutang, atau terdapat pajak yang seharusnya wajib pajak bayarkan namun tidak dibayarkan.

b. Official Assessment System

Ciri-ciri sistem perpajakan Official Assessment:

1) Besarnya pajak terutang dihitung oleh petugas pajak.

2) Wajib pajak sifatnya pasif dalam perhitungan pajak mereka.

3) Pajak terutang ada setelah petugas pajak menghitung pajak yang terutang dan menerbitkan surat ketetapan pajak.

4) Pemerintah memiliki hak penuh dalam menentukan besarnya pajak yang wajib dibayarkan.

c. Withholding System

Besarnya pajak dihitung oleh pihak ketiga yang bukan wajib pajak dan bukan juga aparat pajak/fiskus.

\subsection{Konsep Perpajakan Fintech dari OECD}

Pengaturan perpajakan di Indonesia tidaklah terlepas dari berbagai pengaruh dari pengaturan yang telah disepakati pada beberapa perjanjian antar negara seperti OECD. Praktik tentang aturan Fintech pada OECD telah mengatur sebagaimana berikut dan permasalahan dalam Ekonomi Digital, namun secara garis besar isu tersebut dibagi menjadi dua bagian utama yaitu direct tax (Pajak Penghasilan) dan indirect tax (Pajak Pertambahan Nilai). Isu tersebut antara lain mengenai adanya upaya perusahaan multinasional untuk memiliki kehadiran digital (digital presence) yang signifikan dalam perekonomian suatu negara tanpa harus dikenakan pajak,. Skema Base Erosion and Profit Shifting yang dilakukan oleh perusahaan multinasional saat ini dalam konteks direct taxation (Pajak Penghasilan) menurut OECD BEPS Action 1 terdiri dari empat elemen, yaitu:

a. Meminimalisasi pajak di negara pasar dengan menghindari taxable presence. Dalam hal ini dilakukan baik dengan menggeser gross profit (profit shifting) atau mengurangi laba bersih dengan memaksimalkan pengurangan laba pada tingkat pemberi penghasilan.

b. Pengenaan withholding tax yang rendah atau tidak sama sekali di negara sumber.

c. Pengenaan pajak yang rendah atau tidak sama sekali pada tingkat penerima penghasilan melalui klaim pada pendapatan non-rutin substansial yang seringkali dibentuk melalui skema intra grup.

d. Tidak adanya pemajakan kini (current taxation) dari keuntungan perusahaan atas tarif pajak yang rendah di tingkat ultimate parent company. 


\section{METODE PENELITIAN}

Penelitian ini menggunakan metode kualitatif. Metode ini dipilih karena penulis membutuhkan pemahaman yang lengkap dan rinci tentang masalah yang diteliti. Penulis menggunakan metode deskriptif dan kualitatif dari analisis induktif.

\subsection{Jenis dan Sumber Data}

Sumber data yang digunakan dalam penelitian ini adalah dokumen dan narasumber. Dokumen yang digunakan dalam studi literatur dari buku, artikel, jurnal, focus group discussion dan peraturan.

1. Teknik Pengumpulan Data

Teknik pengumpulan data yang dilakukan dalam penelitian ini adalah:

a. Mengumpulkan dan Meneliti.

Penelitian perpustakaan dilakukan dengan mengumpulkan, membaca, memahami berbagai literatur, buku, artikel, dan laporan yang berkaitan dengan topik penelitian.

b. Wawancara Penelitian lapangan dilakukan dengan mengumpulkan data langsung ke sumber data untuk memperoleh data yang berkaitan dengan objek penelitian melalui wawancara mendalam (indepth interview). Peneliti melakukan wawancara kualitatif dengan mengajukan pertanyaan terbuka yang memungkinkan untuk mode percakapan. Melalui mekanisme ini diharapkan dapat menciptakan hubungan antara peneliti dan informan. Selain itu, penelitian juga dilakukan dengan mengajukan pertanyaan terstruktur dan semi-terstruktur lisan dan tulisan, yang dilakukan melalui tatap muka langsung atau dengan media komunikasi lainnya untuk dijawab oleh narasumber.

\section{Metode Analisis Data}

Dalam suatu penelitian, informasi berupa data baik dari literatur maupun dari sumber-sumber di lapangan penting sebagai bahan analisis penggambaran latar belakang fenomena, penggambaran masalah, perumusan masalah, serta rekomendasi dari hasil analisis. Berikut ini adalah gambaran mengenai bagaimana proses penelitian dan proses analisis data, sebagai berikut:

a. Mengumpulkan informasi-informasi dari narasumber sebagai pelaku $P 2 P$ lending, otoritas kebijakan (BI, OJK, Perpajakan), praktisi bidang IT, untuk mengetahui perkembangan terkini P2P lending, baik dari perkembangan bisnis serta pengaturannya;

b. Setelah didapat informasi-informasi serta data-data terkini disusunlah karakteristik proses bisnis pada P2P lending, menghubungkan dengan aspek-aspek perpajakan kapan timbul kewajiban perpajakan serta dirumuskan pokok-pokok yang menjadi masukan bagi penyusunan aturan perpajakan yang khusus pada P2P lending.

\section{HASIL PENELITIAN}

a. Mekanisme Proses Bisnis P2P Lending dan aspekaspek perpajakan pada $P 2 P$ lending meliputi subyek, obyek, tarif dan prosedur pemungutan serta jenis-jenis pajak.

b. P2P Lending telah muncul sebagai model bisnis yang kredibel, dengan berbagai aliran pendapatan tanpa menanggung risiko pinjaman, menggunakan platform teknologi online sementara investor mendapatkan keuntungan dari pengembalian yang lebih tinggi dan diversifikasi asset. Debitur/borrower memperoleh manfaat dari akses yang mudah, tingkat yang lebih rendah dan proses lebih cepat.

c. Dalam proses bisnis $P 2 P$ lending terdapat tiga komponen yang berperan, yaitu:

1. Platform $P 2 P$ lending sebagai perantara yang menyatukan pemberi pinjaman dan debitur/borrower, memverifikasi kredibilitas debitur/borrower, membantu dalam pengumpulan kredit, dan pada fungsi ini platform $P 2 P$ lending menghasilkan pendapatan yang berasal dari biaya administrasi yang dibebankan kepada debitur/borrower dan biaya penagihan yang dibebankan kepada pemberi pinjaman.

2. Pemberi pinjaman adalah orang atau badan usaha yang memiliki dana untuk disalurkan bekerjasama dengan platform P2P lending, berdasarkan verifikasi kredibilitas debitur/borrower oleh platform P2P lending, pemberi pinjaman menyalurkan dana langsung kepada debitur/borrower, pada dana yang dipinjamkan kepada debitur/borrower, pemberi pinjaman mendapatkan penghasilan dalam bentuk bunga pinjaman dan denda keterlambatan pembayaran pinjaman.

3. Debitur/borrower adalah orang atau badan usaha yang memanfaatkan dana pinjaman dari pemberi pinjaman atas rekomendasi dari platform P2P lending, untuk penggunaan dana ini debitur/borrower dikenakan biaya dalam bentuk biaya administrasi pada awal pinjaman, bunga pinjaman pengguna, biaya keterlambatan pembayaran pinjaman, dan biaya penagihan untuk kegagalan pembayaran kembali pinjaman.

d. Platform $P 2 P$ lending sebagai pengatur kegiatan untuk menentukan hal-hal teknis dalam kegiatan peminjaman dalam ekosistem fintech. Hal ini sejalan dengan teori stakeholder yang menyatakan bahwa semua pemangku kepentingan memiliki hak untuk memperoleh informasi tentang kegiatan perusahaan yang dapat mempengaruhi pengambilan keputusan mereka dan juga sejalan dengan teori agensi yang menyatakan hubungan antara pemegang saham sebagai prinsipal dan manajemen sebagai agen. Manajemen bertanggung jawab kepada pemegang saham karena mereka dikontrak untuk kepentingan pemegang saham. 
e. Dalam mengatur fintech terutama $P 2 P$ lending adalah dengan membuat aturan berdasarkan kebutuhan akan keamanan dan kontinuitas yang dapat dipertanggungjawabkan oleh semua pihak dan dapat mengakomodasi serta memprediksi perkembangan dinamis fintech dan P2P Lending.

Secara umum yang dapat menjadi potensi pajak dari para pelaku lender, borrower, dan platform sebagai subyek pajak dan mekanisme yang dapat menjadi obyek pajak dapat dijelaskan sebagai berikut:

1. Para pelaku lender, borrower, dan platform sebagai subyek pajak dapat dikenakan kewajiban perpajakan berupa pajak penghasilan, pajak pertambahan nilai, maupun bea meterai.

2. Mekanisme terjadinya transaksi akan menimbulkan penghasilan yang dapat dikenakan kewajiban perpajakan berupa pajak penghasilan.

3. Sebagaimana layanan perbankan konvensional maka prosedur pemungutan perpajakan yang dapat dikenakan terhadap transaksi tersebut adalah pajak penghasilan dan pajak pertambahan nilai.

Selanjutnya dapat dirangkum dan dijelaskan dalam tabel terkait variabel kebijakan perpajakan meliputi jenis pajak, subjek pajak, objek pajak, dan prosedur pemungutan pajak dengan tahapan transaksi dalam P2P Lending sebagaimana tabel 4.1.

Tabel 4.1. Transaksi Dalam P2P Landing

\begin{tabular}{|c|c|c|c|c|c|c|c|}
\hline No. & Transaksi & Objek Pajak & $\begin{array}{c}\text { Subjek } \\
\text { Pajak }\end{array}$ & $\begin{array}{l}\text { Jenis } \\
\text { Pajak }\end{array}$ & Tarif & Pemungutan & Usulan \\
\hline \multirow[t]{2}{*}{1} & $\begin{array}{l}\text { Pemberian } \\
\text { Pinjaman }\end{array}$ & \begin{tabular}{|l|} 
Biaya \\
Administrasi
\end{tabular} & \begin{tabular}{|l|} 
P2P \\
Platform
\end{tabular} & $\begin{array}{l}\text { PPh Pasal } \\
25 / 29\end{array}$ & Pasal17 & \begin{tabular}{|l|} 
Self \\
Assessment
\end{tabular} & $\begin{array}{l}\text { Self } \\
\text { Assessment }\end{array}$ \\
\hline & & $\begin{array}{l}\text { Dokumen } \\
\text { Perjanjian }\end{array}$ & Peminjam & \begin{tabular}{|l|} 
Bea \\
Meterai
\end{tabular} & $\begin{array}{c}\text { Rp6.000,00 } \\
\text { dan } \\
\text { Rp3.000,00 }\end{array}$ & \begin{tabular}{|l|} 
Belum \\
Dikenakan
\end{tabular} & Dikenakan \\
\hline \multirow[t]{2}{*}{2} & $\begin{array}{l}\text { Pengembalian } \\
\text { Pinjaman }\end{array}$ & Bunga & Lender & $\begin{array}{l}\text { PPh } \\
\text { (Pasal } \\
\text { Pasal23) }\end{array}$ & $15 \%$ & \begin{tabular}{|l|} 
Self \\
Assessment
\end{tabular} & Dipungut \\
\hline & & \begin{tabular}{|l|} 
Fee \\
Pengurusan
\end{tabular} & \begin{tabular}{|l|} 
P2P \\
Platform
\end{tabular} & \begin{tabular}{|l|} 
PPh \\
Pasal \\
$25 / 29$ \\
\end{tabular} & Pasal17 & $\begin{array}{l}\text { Self } \\
\text { Assessment }\end{array}$ & $\begin{array}{l}\text { Self } \\
\text { Assessment }\end{array}$ \\
\hline \multirow[t]{4}{*}{3} & Penaghan & \begin{tabular}{|l|} 
Fee \\
Penaghan
\end{tabular} & \begin{tabular}{|l|} 
P2P \\
Platform
\end{tabular} & \begin{tabular}{|l|} 
PPh \\
Pasal \\
$25 / 29$ \\
\end{tabular} & Pasal17 & \begin{tabular}{|l|} 
Self \\
Assessment
\end{tabular} & $\begin{array}{l}\text { Self } \\
\text { Assessment }\end{array}$ \\
\hline & & & \begin{tabular}{|l|} 
P2P \\
Platform \\
\end{tabular} & PPN & $10 \%$ & \begin{tabular}{|l|} 
Belum \\
Dikenakan \\
\end{tabular} & Dikenakan \\
\hline & & Bunga & Lender & PPh & $\begin{array}{c}15 \% \\
\text { (PasalPasal } \\
23)\end{array}$ & \begin{tabular}{|l|} 
Self \\
Assessment
\end{tabular} & Dipungut \\
\hline & & \begin{tabular}{|l|} 
Fee \\
Pengurusan
\end{tabular} & $\begin{array}{l}\text { P2P } \\
\text { Platform }\end{array}$ & \begin{tabular}{|l|} 
PPh \\
Pasal \\
$25 / 29$
\end{tabular} & Pasal17 & \begin{tabular}{|l|} 
Self \\
Assessment
\end{tabular} & $\begin{array}{l}\text { Self } \\
\text { Assessment }\end{array}$ \\
\hline
\end{tabular}

Sumber: Penulis

Berdasarkan uraian tersebut dapat diketahui bahwa saat ini tidak ada aturan pajak yang secara khusus mengatur $P 2 P$ Lending, tetapi ada beberapa aturan mengenai pajak penghasilan dan pajak pertambahan nilai yang dapat diterapkan dalam transaksi $P 2 P$ Lending. Masih ada aturan pajak lain yang terkait dengan $P 2 P$ Lending, tetapi tidak ada dampak yang signifikan terhadap perlakuan peraturan pajak sebagai regulator atau penganggaran.

\section{KESIMPULAN DAN SARAN}

\subsection{Kesimpulan}

a. Teknologi keuangan ('FinTech') menggeser paradigma transaksi keuangan dan menuntut perubahan regulasi yang lebih cepat dan adaptif.

b. Pertumbuhan dan besarnya pola transaksi keuangan $P 2 P$ lending berdampak pada penerimaan pajak, komposisi sektor perpajakan, dan pertumbuhan sektor pajak. Pemerintah sebagai regulator perlu mengatur regulasi khusus perpajakan yang meliputi aspek perpajakan yaitu subjek, objek, tarif pajak, mekanisme pemungutan serta aspek-aspek lain yang merupakan karakteristik binis $P 2 P$ lending.

c. Belum ada pengaturan perpajakan yang khusus mengatur mengenai industri $P 2 P$ lending yang mencakup subjek, objek, tarif pajak, dan mekanisme pemungutan.

d. Platform memiliki data yang lengkap mengenai transaksi peminjaman antara borrower dan lender namun belum dioptimalkan oleh regulator perpajakan

\subsection{Rekomendasi}

a. Diperlukan pengaturan khusus dalam ketentuan pajak yang terkait dengan model transaksi dan pengenaan pajak agar lebih sederhana dan memastikan kepatuhan wajib pajak, meliputi:

i. Penyusunan Peraturan Menteri Keuangan tentang pemungut pajak penghasilan pasal 23 atas bunga yang diterima oleh lender.

ii. Penyusunan Peraturan Direktur Jenderal Pajak tentang tata cara pemungutan dan pelaporan pajak penghasilan pasal 23 atas bunga yang diterima oleh lender.

iii. Penyusunan Peraturan Direktur Jenderal Pajak tentang tata cara pemungutan dan pelaporan pajak pertambahan nilai atas jasa penagihan oleh platform.

iv. Penyempurnaan Undang-Undang tentang Bea Meterai guna mengakomodir dokumen elektronik sebagai dokumen yang diperlakukan sebagai subjek Bea Meterai.

c. Otoritas institusi seperti Otoritas Jasa Keuangan Indonesia (OJK) memiliki data yang lengkap berupa laporan dari Platform mengenai transaksi peminjaman antara borrower dan lender tetapi belum dioptimalkan oleh regulator perpajakan.

\section{DAFTAR PUSTAKA}

Adrian A. Gunadi, 2017, OJK, Marketplace Lending - Addressing the Financing Gap 
Alistair Milne, Paul Parboteeah, 2016, European Credit Research Institute., The Business Models and Economics of Peer-to-Peer Lending

Andrew Verstein, 2011, University of California, Davis Vol. 45:445, The Misregulation of Person-toPerson Lending

Andrija Đurović, Journal of Central Banking Theory and Practice, 2017, 2, pp. 149167 Received: 18 September 2016; accepted: 21 January 2017, Estimating Probability of Default on Peer to Peer Market - Survival Analysis Approach

Andy W. Mullineux, Victor Murinde, Review of Development Finance 4 (2014) 66-72, Financial sector policies for enterprise development in Africa

Anna Omarini, MPRA Paper No. 85228, posted 20 March 2018, The Digital Transformation in Banking and The Role of FinTechs in the New Financial Intermediation Scenario

Anonim (2018) Sumber: Strategic Direction, Vol. 34 Issue: 2, pp.18-20, 2018, Securing The Future of Finance in Hong Kong: The Role of Fintech in Hong Kong's Global Financial Center

Arner, DW; Barberis, JN; Buckley, RP, 2015, The Evolution of FinTech: A New Post-Crisis Paradigm?

Arnoud W.A. Boot, European Economy Banks, Regulation, and the Real Sector 2017, The Future of Banking: From Scale \& Scope Economies to Fintech

Atsushi Samitsu (Bank of Japan) Research LAB No17-E-6, October 23, 2017, Structure of P2P lending and investor protection: Analyses based on an international comparison of legal arrangements

Boris Vallee, Yao Zeng, 2018, Working Paper 18067, Marketplace Lending: A New Banking Paradigm?

Boryana Madzharova, 2017, University of Erlangen-Nuremberg, The impact of cash and card transactions on VAT collection efficiency

Calebe de Roure, Loriana Pelizzon, Paolo Tasca, Discussion Paper Deutsche Bundesbank No 30/2016, How does $\mathrm{P} 2 \mathrm{P}$ lending fit into the consumer credit market?

Carmen Leong, Barney Tan, Xiao Xiao, Felix Ter Chian Tan, Yuan Sun/2017/International Journal of Information Management, Nurturing a FinTech ecosystem: The case of a youth microloan startup in China

Chang-hsien TSAl; Kuan-Jung PENG, Asian Journal of Law and Society, 1017, The FinTech Revolution and Financial Regulation: The Case of Online Supply-Chain Financing
Christian Haddad, , Lars Hornuf, Research Papers in Economics, No. 10/16, 2016, The Emergence of the Global Fintech Market: Economic and Technological Determinants on Networked Business

Daniel Heller and Edwin M. Truman, Journal of International Affairs, 2017, International Financial Regulatory Cooperation and Digital Currencies International Financial Regulatory Cooperation and Digital Currencies.

David LEE Kuo Chuen, Sim Kee Boon, Ernie G.S. Teo, The Journal of Financial Perspectives, 2015, Emergence of FinTech and the LASIC principles

Davy Lust, 2017, Aantal woorden/ Word count: 12.659, ANALYISIS OF SCORING IN PEER-TO-PEER LENDING DETERMINANTS OF LOAN DEFAULT

De Liu, Daniel J. Brass, Yong Lu, Dongyu Chen, MIS Quarterly Vol. 39 No. 3, pp. 729742/September 2015, FRIENDSHIPS IN ONLINE PEER-TO-PEER LENDING: PIPES, PRISMS, AND RELATIONAL HERDING

Derayah Financial, October 2017, A Concept Study on Peer-to-Peer Lending

DIRK A. ZETZSCHE, ROSS P. BUCKLEY, DOUGLAS W. ARNER and JANOS N. BARBERIS, 2017, FROM FINTECH TO TECHFIN: THE REGULATORY CHALLENGES OF DATADRIVEN FINANCE

Dirk A. Zetzsche, Ross P. Buckley, Janos N. Barberis, and Douglas W. Arner, 2016, Regulating a Revolution: From Regulatory Sandboxes to Smart Regulation

Douglas W. Arner, Jànos Barberis, and Ross P. Buckley, 2017 by Douglas Arner, Janos Barberis, and Ross P. Buckley Printed in the U.S.A., FinTech, RegTech, and the Reconceptualization of Financial Regulation Northwestern Journal of International Law \& Business Vol. 37, No. 3

Douglas W. Arner, Jànos BarberisThe Journal of Financial Perspectives, Winter 2015, FinTech in China: from the shadows?

Eduardo Dávila, Harvard University, JOB MARKET PAPER, November 2013, Optimal Financial Transaction Taxes

Fabio Braggion,Alberto Manconi, Haikun Zhu, 2017, Is FinTech a Threat to Financial Stability? - Evidence from Peer-to-Peer Lending in China, LENDERS AND BORROWERS' STRATEGIES IN ONLINE PEER-TO-PEER LENDING MARKET: AN EMPIRICAL ANALYSIS OF PPDAI.COM

Feng et al.: Lenders \& Borrowers' Strategies in Online P2P Lending, 2016

Gareth W. Peters, Ariane Chapelley, The Journal of Financial Perspectives, winter 2015, 
Trends in cryptocurrencies and blockchain technologies: a monetary theory and regulation perspective

Guido Ferrarini, European Economy Banks, Regulation, and the Real Sector, 2017, Regulating FinTech: Crowdfunding and Beyond

Heribert Dieter, GARNET Working Paper No. 78/10, August 2010, Potential and Risks of a Financial Transaction Tax

HONGKE ZHAO, YONG GE, QI LIU, GUIFENG WANG, ENHONG CHEN, and HEFU ZHANG, ACM Transactions on Intelligent Systems and Technology, Vol. 8, No. 6, Article 72, 2017, P2P Lending Survey: Platforms, Recent Advances and Prospects

Ian Galloway, Community Investments, Winter 2009/2010, Peer-to-Peer Lending and Community Development Finance

Imran Gulamhuseinwala, Thomas Bull, Steven Lewis, The Journal of Financial Perspectives, Winter 2015, FinTech is gaining traction and young, highincome users are the early adopters, Fintech: Ecosystem, business models, investment decisions, and challenges

James Kamau Muiruri and James Mark Ngari, International Journal of Humanities and Social Science Vol. 4, No. 7; 2014, Effects of Financial Innovations on the Financial Performance of Commercial Banks in Kenya

Jean Dermine, European Economy Banks, Regulation, and the Real Sector,2017, Digital Disruption and Bank Lending

Jeong Hee Yeo, Patti J. Fisher, Journal of Education \& Social Policy Vol. 7, No. 1; March 2017, Digital Disruption and Bank Lending, Mobile Financial Technology and Consumers' Financial Capability in the United States

John P Wentzel, Krishna Sundar Diatha \& VSS Yadavalli, 2016, An application of the extended Technology Acceptance Model in understanding technologyenabled financial service adoption in South Africa

Julio López-Laborda, Guillermo Peña, International Center for Public Policy Working Paper 16-06, 2016, A new approach to financial VAT

JürgenHuber, Daniel Kleinlerchera, Michael Kirchlerab, 2016, Austrian Science Fund (FWF), The impact of a financial transaction tax on stylized facts of price returns-Evidence from the lab

Keke Gai, Meikang Qiu, Xiaotong Sun/2017/Journal of Network and Computer Applications, A survey on FinTech
KEVIN DAVIS, JACOB MURPHY, JASSA The Finsia Journal of Applied Finance ISSUE 3 2016, PEER-TO-PEER LENDING: Structures, risks and regulation

Kevin Williams1, Samir Chatterjee1 and Matti Rossi2 European Journal of Information Systems (2008) 17, 505517, Design of emerging digital services: a Taxonomy \& 2008 Operational Research Society Ltd. All rights reserved 0960-085X

Kyle Jackson,University of California, Berkeley, 2016, A Detailed Look into Peer to Peer Lending

Leire San-Jose, Jose-Luis Retolaza, Maite RuizRoqueñi, Sara Urionabarrenetxea, International Research Journal of Finance and Economics - Issue 103 (2013), The New Paradigm of Corporate Finance: Ethics in Finance, ICTs, Financial Globalization and Stakeholder Responsibility

Li Liu, Tim Schmidt-Eisenlohr, and Dongxian Guo, International Finance Discussion Papers Number 1214, October 2017 , International Transfer Pricing and Tax Avoidance: Evidence from Linked Trade-Tax Statistics in the UK

Magdalena Lestari GINTING, Rehnalemken GINTING, I Gusti Ayu Ketut Rachmi HANDAYANI, nternational Journal of Social Science and Economic Research ISSN: 2455-8834, Volume:03, Issue:03 "March 2018", DIFFUSION INNOVATION AT FINANCIAL TECHNOLOGY AND CYBER LAW IN INDONESIA

Małgorzata Twarowska, Jolanta Szołno-Koguc, Management Knowledge and Learning, International Conference Slovenia, 2014, THE IMPACT OF FINANCIAL SECTOR TAXATION ON FINANCIAL MARKET STABILITY

Marcello Bofondi and Giorgio Gobbi, European Economy Banks, Regulation, and the Real Sector,2017, The Big Promise of Fintech

Mark Fenwick, Joseph A. McCahery, Erik P.M. Vermeulen,ECGI Working Paper Series in Law Working Paper $N^{\circ} 369 / 2017$, September 2017, Fintech and the Financing of Entrepreneurs: From Crowdfunding to Marketplace Lending

Massimo Pizzola*, Elena Vighia, Romain Sacchia, Procedia CIRP 69 ( 2018 ) 633 - 637, Challenges in coupling digital payments data and input-output data to change consumption patterns

Michael Mainelli, Mike Smith, The Journal of Financial Perspectives, Winter 2015, Sharing ledgers for sharing economies: 
an exploration of mutual distributed ledgers (aka blockchain technology)

Miriam Segal, Issue Briefs are produced in the Office of Economic Research of the Office of Advocacy, 2014, Peer-to-Peer Lending: A Financing Alternative for Small Businesses

Muhammad Aldi Nizar/2017/Warta Fiskal, Edisi 115, 2017, Teknologi Keuangan (Fintech): Konsep dan Implementasinya di Indonesia

Musa Abdullahi Bayero, Procedia - Social and Behavioral Sciences 172 ( 2015 ) 49 56, Effects of Cashless Economy Policy on financial inclusion in Nigeria: An exploratory study

Neil Tomlinson, 2017, Delloite, A temporary phenomenon? Marketplace lending An analysis of the UK market

Ng, Artie, Benny K.B. Kwok (2017) Sumber: Journal of Financial Regulation and Compliance, 2017, Emergence of Fintech and Cybersecurity in a Global Financial Centre: Strategic Approach by a Regulator

Olena Havrylchyk, Carlotta Mariotto, Talal Rahim, Marianne Verdier, 2016, What drives the expansion of the peer-to-peer lending?

Pant, Abhishant . Express Computer ; Mumbai (Jun 2, 2016), Cashless in India: How a fintech professional went without using cash for 50 days

Patrick Schueffel, Journal of Innovation Management Schueffel JIM 4, 4 (2016) 32-54, Taming the Beast: A Scientific Definition of Fintech HANDLE: http://hdl.handle.net/10216/102610

Pei Sai Fan, 2018, Handbook of Blockchain, Digital Finance, and Iclusion, Vol. 1: Chapter 15 - Singapore Approach to Develop and Regulate FinTech

Peter Gomber, Robert J. Kauffman, Bruce W. Weber, May 9, 2015, The Economist, FINANCIAL IS, UNDERLYING TECHNOLOGIES, AND THE FINTECH REVOLUTION

Philip Arestis dan Malcolm Sawyer, Economic Policies, Governance and the New Economics, 2017, The Potential of Financial Transactions Taxes

Philip Treleaven, The Journal of Financial Perspectives: FinTech, EY Global Financial Services Institute Winter 2015 | Volume 3 - Issue 3, Financial Regulation on Fintech

Philip Treleaven, The Journal of Financial Perspectives, Winter 2015, Financial regulation of FinTech

Proquest (Winter 2017): 5563.DOI:10.3905/jpe.2017.21.1.055, Fintech Crowdfunding of Thailand 4.0
Publication info: Mint ; New Delhi [New Delhi]23 June 2015, Cashless economy: Checks on tax evasion, transaction trails will be easier

Reserve Bank of India, April 2016, CONSULTATION PAPER ON PEER TO PEER LENDING

Reynold Wijaya, 2017, Fintech Indonesia, "P2P Lending: Wujud Baru Inklusi Keuangan"

Rita de la Feria and Richard Ness, canadian tax journal / revue fiscale canadienne (2016) 64:2, 373 - 87, Policy Forum: The EU Financial Transaction Tax as an Unsuitable and Unnecessary Proxy Tax

Ryu, Hyun-Sun (2017) Sumber: Industrial Management \& Data Systems, 2017, What Makes Users Willing or Hesitant to Use Fintech?: The Moderating Effect of User Type

SAIM 12000, Technical Guidance Note 24 March 2016, Income tax relief for irrecoverable peer to peer loans

SHAIRIL IZWAN TAASIM AND REMALI YUSOFF, Journal of Business and Social Development, Volume 3 Number 1, March 2015: 1-11, ARE MALAYSIAN STILL TECHNOPHOBIA ABOUT EFINANCE PRODUCT: A LITERATURE REVIEW

Shen, Yan, Yiping Huang (2016) Sumber: China Economic Journal, Introduction to the special issue: Internet finance in China

Simla Ceyhan, Xiaolin Shi, Jure Leskovec, International World Wide Web Conference Committee, (IW3C2), 2016, Dynamics of Bidding in a P2P Lending Service: Effects of Herding and Predicting Loan Success

Stewart, Harrison, Jan Jürjens (2018) Sumber: Information \& Computer Security, Vol. 26 Issue: 1, pp.109-128, 2018, Data Security and Consumer Trust in FinTech Innovation in Germany

Sue Yasav, The Journal of Financial Perspectives, Winter 2015, The impact of digital technology on consumer purchase behavior

Sumit Kamra, 2014, (C) 2014 Happiest Minds. All Rights Reserved, The Peer-to-Peer (P2P) Marketplace

Svetlana Saksonova, Irina Kuzmina-Merlino, European Research Studies Journal, Volume XX, Issue 3A, 2017, Fintech as Financial Innovation - The Possibilities and Problems of Implementation

Swartz, Kristi (2017) Sumber: Journal of Investment Compliance, Vol. 18 Issue: 1, 2017, Stored Value Facilities: Changing The Fintech Landscape in Hong Kong

Tae-heon Le1, and Hee-Woong Kim, 2016, An eksploratory study on Fintech Industry in Korea ; crrowdfunding case 
Takeshi Jingu, lakyara vol.202, 10. September. 2014, Risks and opportunities in China's growing P2P lending market

The Association of Chartered Certified Accountants, October 2015, The rise of peer to peer lending in China: An overview and survey case study

Thomas Hemmelgarn, Gaëtan Nicodème, Bogdan Tasnadi, and Pol Vermote, TAXATION PAPERS, Taxation and Customs Union, WORKING PAPER N. 62 - 2015, Financial Transaction Taxes in the European Union

Thornton Matheson, 2010, IMF Working Paper, Taxing Financial Transactions: Issues and Evidence

Tomáš Chloubaa, Monika Šimkováb, Procedia Social and Behavioral Sciences 28 (2011) 370 - 373, Application for education of financial literacy

Peer-to-peer lending to small businessesTraci L. Mach, Courtney M. Carter, and Cailin R. Slattery, 2014,

W. Scott Frame* \& Lawrence J. White, 2016, w4.stern.nyu.edu, TECHNOLOGICAL CHANGE, FINANCIAL INNOVATION, AND DIFFUSION IN BANKING

WILLIAM S. WARREN, 2016, DUKE LAW \& TECHNOLOGY REVIEW, THE FRONTIERS OF PEER-TO-PEER LENDING: THINKING ABOUT A NEW REGULATORY APPROACH

Wonglimpiyarat, Jarunee (2017) Sumber: foresight, Vol. 19 Issue: 6, pp.590-603, 2017, FinTech Banking Industry: A Systemic Approach

Xavier Vives, European Economy Banks, Regulation, and the Real Sector 2017, The Impact of Fintech on Banking

Xiangyu Wang1, Yan Tu, The International Journal of Social Sciences and Humanities Invention 4(1): 3202-3214, 2017, A Study on P2P Lending Mode using Generalized Stochastic Petri Nets

Xiao Xiang, Zhang Lina, Wang Yun and Huang Chengxuan, European Economy Banks, Regulation, and the Real Sector 2017, China's Path to FinTech Development

Xiaoni Wen, Zhenqi Zhang, Xiaojuan Wu, Advances in Economics and Business 5(1): 11-17, 2017, A Research on the Influence Factors of P2P Lending Market

Yao Zeng, Yao Zeng, 2018, Working Paper 18-067 Harvard Business School, Organizing for Innovation in the Digitized World, Marketplace Lending: A New Banking Paradigm?

Youngjin Yoo Richard J. Boland Jr., Kalle Lyytinen Ann Majchrzak Organization Science Vol. 23, No. 5, September-October
2012, pp. 1398-1408 ISSN 1047-7039 (print). ISSN 1526-5455 (online)

Zaiyan Wei, Mingfeng Lin (2016) Market Mechanisms in Online Peer-to-Peer Lending. Management Science Published online in Articles in Advance 07 Sep 2016, Market Mechanisms in Online Peer-to-Peer Lending

ZORAN TEMELKOV, MARIJA GOGOVA SAMONIKOV, VOLUME 10 NUMBER 3 Aug 2018, International Journal of Information, Business and Management, THE NEED FOR FINTECH COMPANIES AS NON-BANK FINANCING ALTERNATIVES FOR SME IN DEVELOPING ECONOMIES 